NOTE

\title{
First record of the microsporidian parasite Steinhausia mytilovum in Mytilus sp. (Bivalvia: Mytilidae) from France
}

\author{
Thierry Comtet ${ }^{1,2, *}$, Céline Garciaa ${ }^{1,3}$, Yvette Le Coguic ${ }^{1}$, Jean-Pierre Joly ${ }^{1,3}$ \\ ${ }^{1}$ Laboratoire Conchylicole de Bretagne, IFREMER, Station de la Trinité-sur-Mer, 12 rue des résistants, BP 26, \\ 56470 La Trinité-sur-Mer, France \\ ${ }^{2}$ UMR CNRS-UPMC 7127, Equipe Ecologie Benthique, Station Biologique, BP 74, 29682 Roscoff Cedex, France \\ ${ }^{3}$ Laboratoire Génétique et Pathologie, IFREMER, Station de la Tremblade, Ronce-les-Bains, BP 133, \\ 17390 La Tremblade, France
}

\begin{abstract}
Steinhausia mytilovum is a globally distributed microsporidian parasite which infects the oocytes of the blue mussels Mytilus edulis and M. galloprovincialis. Despite the intensive monitoring effort made on mussel populations, the parasite has not previously been reported in France. We report herein on the occurrence of $S$. mytilovum in Mytilus sp. from 1 cultured and 2 natural populations on the northern coast of France, thus extending the parasite's known distribution northwards. We also report on the observation in 1989 of S. mytilovum in M. galloprovincialis from the Golfe de Fos area in the Mediterranean Sea (South of France). S. mytilovum was observed in the European hybrid zone between $M$. edulis and $M$. galloprovincialis, which therefore renders the exact taxonomic status of the infected hosts unknown. The prevalence of the parasite was low, which suggests that its effect on mussel populations was probably limited.
\end{abstract}

KEY WORDS: Mytilus edulis · Mytilus galloprovincialis $\cdot$ Steinhausia mytilovum · Microsporidia · Parasite $\cdot$ Aquaculture

\section{INTRODUCTION}

Microsporidia are obligate intracellular parasites infecting many animal groups, including marine molluscs (Bower et al. 1994, Wittner \& Weiss 1999). In bivalves, microsporidians have been recorded from several tissues of numerous species (Comtet et al. 2003). In particular, a few microsporidian species belonging to the genus Steinhausia have been described as infecting the oocytes of several bivalve species: $S$. ovicola in the European flat oyster Ostrea edulis (see Léger \& Hollande 1917), S. mytilovum in the mytilid mussels Mytilus edulis and $M$. galloprovincialis (see Field 1921-1922, de Vincentiis \& Renzoni 1963, Sprague 1965, Figueras et al. 1991), and Steinhausia spp. in the Sydney rock oyster Saccostrea commercialis (see Anderson et al. 1995), the tellinid clam
Macoma balthica (see Farley 1977), the clam Venerupis pullastra (see Villalba et al. 1993) and the common cockle Cerastoderma edule (see Carballal et al. 2001, Comtet et al. 2003).

Steinhausia mytilovum (formerly Haplosporidium mytilovum and Chytridiopsis mytilovum) has a wide geographical range, occurring in both natural and cultured populations of Mytilus edulis and M. galloprovincialis from the Atlantic and Pacific coasts of the USA, Europe and Asia (Table 1). However, despite the intense survey of cultured mussel populations along the French coasts, $S$. mytilovum has never before been reported in France.

In this paper, we report for the first time the occurrence of Steinhausia mytilovum in French production areas and natural mussel populations. 
Table 1. Steinhausia mytilovum. Known distribution of the parasite in cultured (C) and natural (N) populations of Mytilus species

\begin{tabular}{|c|c|c|c|c|c|}
\hline Host species & Location & Type & Sample size & Prevalence (\%) & Source \\
\hline M. edulis & $\begin{array}{l}\text { Northeast coast of USA } \\
\text { Maryland, northeast coast of USA } \\
\text { East coast of USA, south of Cape Cod, MA }\end{array}$ & $\begin{array}{l}- \\
\mathrm{N} \\
\mathrm{N}\end{array}$ & $\begin{array}{c}- \\
30 \text { (females) } \\
-\end{array}$ & $\begin{array}{c}- \\
43^{\mathrm{a}, \mathrm{b}} \\
-\end{array}$ & $\begin{array}{l}\text { Field (1921-1922) } \\
\text { Sprague (1965) } \\
\text { Farley (1988) }\end{array}$ \\
\hline M. galloprovincialis & $\begin{array}{l}\text { Marina del Rey, California, west coast of USA } \\
\text { Gulf of Naples, west coast of Italy } \\
\text { Lake Fusaro, Bay of Bacoli, west coast of Italy } \\
\text { Ria de Arosa, Ria de Ares-Betanzos, NW Spain } \\
\text { Ria de Arosa, NW Spain } \\
\text { Ria de Vigo, NW Spain } \\
\text { Rias of Galicia, NW Spain } \\
\text { Mediterranean coast of Spain } \\
\text { Thermaikos Gulf, North Aegean Sea, Greece } \\
\text { Northwest Black Sea }\end{array}$ & $\begin{array}{l}\mathrm{N} \\
- \\
\mathrm{C} \\
- \\
\mathrm{C} \\
\mathrm{C} \\
\mathrm{C} \\
\mathrm{N} \\
\mathrm{C} \\
\mathrm{N} / \mathrm{C}\end{array}$ & $\begin{array}{c}50 \\
- \\
133 \\
- \\
330 \\
- \\
2430 \\
174 \\
127 \text { (females) } \\
\text { About } 3000\end{array}$ & $\begin{array}{c}5-10^{\mathrm{c}} \\
10^{\mathrm{c}} \\
0-15^{\mathrm{c}} \\
- \\
7.5-12.5^{\mathrm{a}} \\
3.3-19.5^{\mathrm{d}} \\
\text { Up to } 28.3^{\mathrm{a}} \\
17.6-50^{\mathrm{a}} \\
7.5-35.5^{\mathrm{a}} \\
\text { Up to } 76^{\mathrm{a}}\end{array}$ & $\begin{array}{l}\text { Hillman (1991) } \\
\text { de Vincentiis \& Renzoni (1963) } \\
\text { Ceschia (pers. comm. 2003) } \\
\text { Gonzales et al. (1987) } \\
\text { Figueras et al. (1991) } \\
\text { Robledo et al. (1994) } \\
\text { Villalba et al. (1997) } \\
\text { Sagristà et al. (1998) } \\
\text { Rayyan \& Chintiroglou (2004) } \\
\text { Rybakov \& Kholodkovskaya (1987) }\end{array}$ \\
\hline $\begin{array}{l}\text { Mytilus sp. } \\
{ }^{\mathrm{a} C} \text { Calculated in relat } \\
{ }^{\mathrm{b}} \text { Observations made } \\
{ }^{\mathrm{c}} \text { Calculated in relat } \\
{ }^{\mathrm{d}} \text { Mode of calculatio }\end{array}$ & $\begin{array}{l}\text { Korea and Japan } \\
\text { to the number of females } \\
\text { om fresh smears } \\
\text { to the total number of individuals } \\
\text { total number of individuals vs females }\end{array}$ & - & - & - & Hine (1999) \\
\hline
\end{tabular}

\section{MATERIALS AND METHODS}

The present work was carried out within the framework of the French REPAMO network (IFREMER), which aims at surveying pathogens in harvested and cultured populations of molluscs from French production areas. As part of the sampling strategy of this survey program, samples of 30 living mussels were collected from 3 natural or cultured populations (see Fig. 1): Mytilus edulis specimens were sampled from a natural harvested subtidal population at Barfleur on 4 July 2000 (40 m depth), natural M. galloprovincialis were collected intertidally in the Baie de Saint-Brieuc (Le Rocher Martin, Plérin) on 13 June 2000, and cultured M. galloprovincialis were collected in Utah

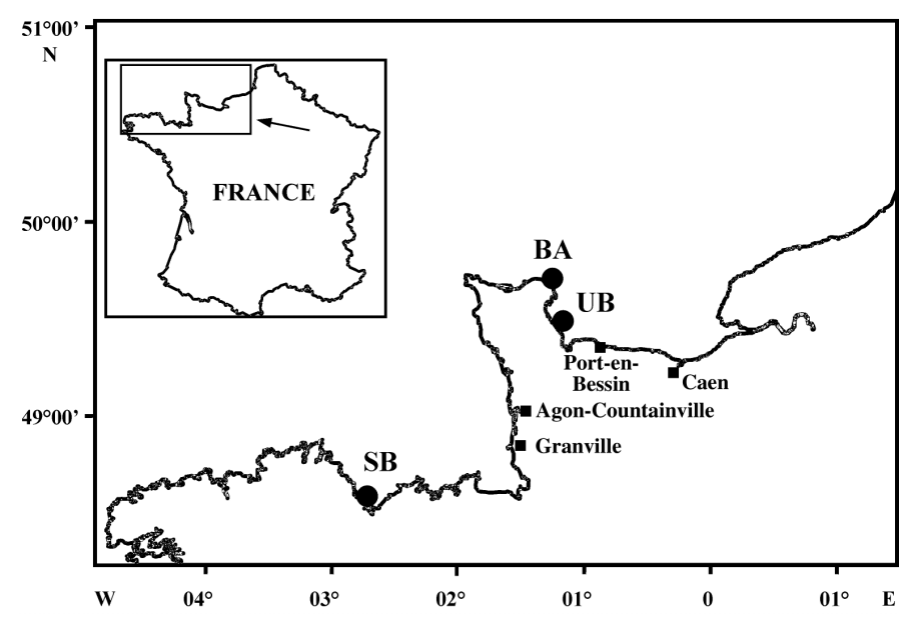

Fig. 1. Location of the sampling sites: Baie de Saint-Brieuc (SB), Barfleur (BA) and Utah Beach (UB)
Beach (Normandy) on 2 May 2001. The latter originated from a 1996 spat collection in the Mediterranean Sea and were transferred to Utah Beach in 1997.

To evaluate their histopathological state, mussels were dissected and tissues fixed for $24 \mathrm{~h}$ in Davidson's fixative (Shaw \& Battle 1957). They were dehydrated and embedded in paraffin. Sections of 2 to $3 \mu \mathrm{m}$ thickness were cut, stained with hematoxylin-eosin and examined with light microscopy.

Due to its location in the oocytes, Steinhausia mytilovum infects only females or hermaphrodites. Thus, its prevalence was calculated only from female and hermaphrodite data (only 1 hermaphrodite was observed at Utah Beach) as previously done by Villalba et al. (1997) for S. mytilovum in Mytilus galloprovincialis. Neither males nor immature individuals were considered.

\section{RESULTS AND DISCUSSION}

Four mussels were infected by Steinhausia mytilovum in the 3 populations (Table 2). The parasite appeared as cysts containing many spores and delimited by a thin membrane (Fig. 2). The cysts were mostly located in the oocyte cytoplasm, but a few were also observed in the nucleus. Most of the infected oocytes contained a single cyst, but multiple infections with 2 parasites in the cytoplasm were observed in a few cases. Prevalences were between 5.9 and 18.2\% (Table 2) and were in the range of most of those previously reported (Table 1), although prevalences of up to $76 \%$ of the females examined were recorded in M. galloprovincialis from the northwest Black Sea (Rybakov \& Kholodkovskaya 1987). 
Table 2. Steinhausia mytilovum. Prevalence in female (and hermaphrodite) Mytilus edulis and Mytilus galloprovincialis from 3 French populations

\begin{tabular}{|lccccc|}
\hline Species & Location & Origin & $\begin{array}{c}\text { Number of } \\
\text { females }\end{array}$ & $\begin{array}{c}\text { Number of infected } \\
\text { females }\end{array}$ & Prevalence (\%) \\
\hline M. edulis & Barfleur & Local recruitment & 11 & 2 & 18.2 \\
M. galloprovincialis & Saint-Brieuc & Local recruitment & 17 & 1 & 5.9 \\
M. galloprovincialis & Utah Beach & Mediterranean Sea & 15 & 1 & 6.7 \\
a Hermaphrodites included & & & & & \\
\hline
\end{tabular}

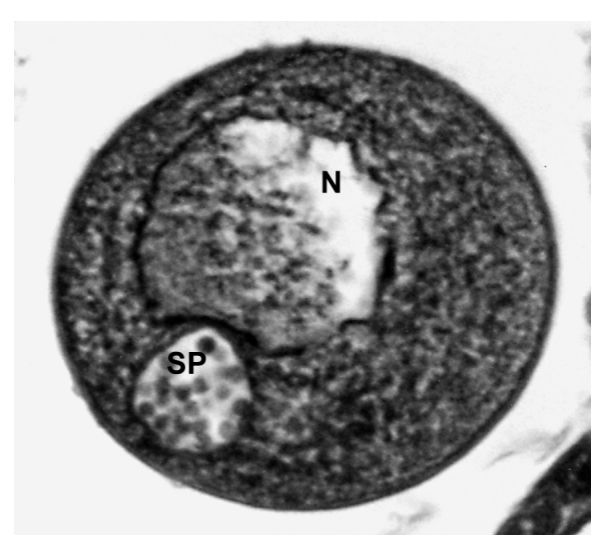

Fig. 2. Steinhausia mytilovum in Mytilus edulis from Barfleur. Histological section in gonadal tissue stained with hematoxylin-eosin (750×), showing a sporocyst (SP) located close to the host cell nucleus $(\mathrm{N})$

To our knowledge, this is the first published record of Steinhausia mytilovum in Mytilus spp. in France, and has increased the known geographic distribution of this parasite to the north. However, S. mytilovum was found in 1989 in M. galloprovincialis from Carteau (Golfe de Fos-sur-Mer, Mediterranean coast of France; Y. Pichot pers. comm.). Careful examination of additional $M$. edulis collected in the Barfleur population in 1999 and 2001 (6 and 16 females, respectively) did not reveal $S$. mytilovum. Moreover, despite the intensive monitoring effort made on mussel populations in France, within the national REPAMO network (between 1990 and 2001, 5041 mussels were analysed in France, including 2962 from the northern coast of France), S. mytilovum was never observed in samples other than those in the present study. This suggests that $S$. mytilovum has only recently been introduced to the northern coast of France. However, both its low prevalence (Table 2) and its overall low intensity of infection (a few oocytes per slide were infected, with the exception of the female from the Baie de SaintBrieuc with more than 50 infected oocytes on a single slide) could also explain why it has only recently been detected. Several factors such as climate warming (Cook et al. 1998, Harvell et al. 2002) and transfer of infected hosts related to aquacultural practices (e.g.
Naylor et al. 2001) are known to favour the geographic range extension of parasites, but our data did not allow us to propose such hypotheses in the case of $S$. mytilovum.

Steinhausia mytilovum was found in the European mosaic hybrid zone between Mytilus edulis and $M$. galloprovincialis (see Coustau et al. 1991, Daguin et al. 2001, Bierne et al. 2003), which therefore renders the exact taxonomic status of the infected individuals unknown. Thus, if mussels cultured at Utah Beach are M. galloprovincialis (originating from the Mediterranean Sea), natural mussel populations from Barfleur and Baie de Saint-Brieuc could in fact be the result of a mixing of $M$. edulis, M. galloprovincialis and hybrids. Indeed, in a natural population of the Baie de SaintBrieuc (exact location unknown), M. galloprovincialis and $M$. edulis co-occur, and hybridisation has been shown to be partial (Coustau et al. 1991). Conversely, the Barfleur mussels are most likely $M$. edulis, as $M$. edulis-like genotypes are highly dominant in populations surrounding Barfleur, i.e. Granville, AgonCoutainville, Port-en-Bessin and Caen (Fig. 1) (Coustau et al. 1991, Bierne et al. 2003).

The effect of Steinhausia mytilovum on its host is still unclear. A strong haemocytic host response has been reported in Mytilus galloprovincialis (see González et al. 1987, Bower \& Figueras 1989, Figueras et al. 1991, Villalba et al. 1997, Sagristà et al. 1998), but no conclusive evidence has been reported regarding the viability of the infected oocytes. However, due to its location in the oocytes, numerous authors considered that $S$. mytilovum may affect the reproduction of their host (González et al. 1987, Bower \& Figueras 1989, Figueras et al. 1991, Robledo et al. 1994, Villalba et al. 1997). In the present study, the prevalence of $S$. mytilovum was low and no haemocyte infiltration was observed, even in the case of high infection intensity (i.e. the female from Baie de Saint-Brieuc), which suggests a limited effect on mussel reproduction at the population level. Further monitoring of the mussel populations along the French coasts is needed in order to follow the evolution of the S. mytilovum extension and to better assess its potential impact on both the natural and cultured Mytilus sp. populations. 
Acknowledgements. We are indebted to the staff of the Laboratoire côtier de Port-en-Bessin and Laboratoire côtier de Saint-Malo (IFREMER) for collecting samples. We acknowledge the coordinator of the REPAMO program, A. Thébault (IFREMER, Station de La Tremblade), for her assistance, Y. Pichot (IFREMER, Station de Sète) for reporting to us the occurrence of Steinhausia mytilovum in Mytilus galloprovincialis in the Golfe de Fos-sur-Mer and M.-A. Lekkas for improving the English of the text. We thank G. Ceschia (Istituto Zooprofilattico Sperimentale Delle Venezie), who provided us with unpublished data. Three anonymous reviewers provided helpful comments on the manuscript. This work was supported by IFREMER and CNRS.

\section{LITERATURE CITED}

Anderson TJ, Hine PM, Lester RJG (1995) A Steinhausia-like infection in the ovocytes of Sydney rock oysters Saccostrea commercialis. Dis Aquat Org 22:143-146

Bierne N, Borsa P, Daguin C, Jollivet D, Viard F, Bonhomme F, David P (2003) Introgression patterns in the mosaic hybrid zone between Mytilus edulis and M. galloprovincialis. Mol Ecol 12:447-461

Bower SM, Figueras AJ (1989) Infectious diseases of mussels, especially pertaining to mussel transplantation. World Aquac 20:89-93

Bower SM, McGladdery SE, Price IM (1994) Synopsis of infectious diseases and parasites of commercially exploited shellfish. Annu Rev Fish Dis 4:1-199

Carballal MJ, Iglesias D, Santamarina J, Ferro-Soto B, Villalba A (2001) Parasites and pathologic conditions of the cockle Cerastoderma edule populations of the coast of Galicia (NW Spain). J Invertebr Pathol 78:87-97

Comtet T, Garcia C, Le Coguic Y, Joly J-P (2003) Infection of the cockle Cerastoderma edule in the Baie des Veys (France) by the microsporidian parasite Steinhausia sp. Dis Aquat Org 57:135-139

Cook T, Folli M, Klinck J, Ford S, Miller J (1998) The relationship between increasing sea-surface temperature and the northward spread of Perkinsus marinus (Dermo) disease epizootics in oysters. Estuar Coast Shelf Sci 46:587-597

Coustau C, Renaud F, Delay B (1991) Genetic characterization of the hybridization between Mytilus edulis and M. galloprovincialis on the Atlantic coast of France. Mar Biol 111:87-93

Daguin C, Bonhomme F, Borsa P (2001) The zone of sympatry and hybridization of Mytilus edulis and M. galloprovincialis, as described by intron length polymorphism at locus mac-1. Heredity 86:342-354

de Vincentiis M, Renzoni A (1963) Sulla presenza di uno sporozoo in ovociti di Mytilus galloprovincialis Lam. Arch Zool Ital 47:21-26

Farley CA (1977) Neoplasms in estuarine mollusks and approaches to ascertain causes. Ann NY Acad Sci 298:225-232

Farley CA (1988) A computerized coding system for organs, tissues, lesions, and parasites of bivalve mollusks and its application in pollution monitoring with Mytilus edulis. Mar Environ Res 24:243-249
Field IA (1921-1922) Biology and economic value of the sea mussel Mytilus edulis. Bull US Bur Fish 38:127-259

Figueras AJ, Jardón CF, Caldas JR (1991) Diseases and parasites of rafted mussels (Mytilus galloprovincialis Lmk): preliminary results. Aquaculture 99:17-33

González P, Pascual C, Quintana R, Morales J (1987) Parásitos del mejillón gallego cultivado: 1. Protozoos con especial referencia a Marteilia maurini y Steinhausia mytilovum. Alimentaria 24:37-44

Harvell CD, Mitchell CE, Ward JR, Altizer S, Dobson AP, Ostfeld RS, Samuel MD (2002) Climate warming and disease risks for terrestrial and marine biota. Science 296: $2158-2162$

Hillman RE (1991) Steinhausia mytilovum (Minisporida: Chitridiopsidae) in Mytilus sp. in California: a new geographic record. J Invertebr Pathol 57:144-145

Hine PM (1999) Significant diseases of molluscs in the AsiaPacific region. Fourth symposium on diseases in Asian aquaculture: aquatic animal health for sustainability. Asian Fisheries Society, Cebu City, The Philippines

Léger L, Hollande AC (1917) Sur un nouveau protiste à facies de Chytridiopsis, parasite des ovules de l'huître. CR Séances Soc Biol Paris 80:61-64

Naylor RL, Williams SL, Strong DR (2001) Aquaculture: a gateway for exotic species. Science 294:1655-1656

Rayyan A, Chintiroglou CC (2004) Steinhausia mytilovum in cultured mussel Mytilus galloprovincialis in the Thermaikos Gulf (north Aegean Sea, Greece). Dis Aquat Org 57:271-273

Robledo JAF, Santarém MM, Figueras AJ (1994) Parasite loads of rafted blue mussels (Mytilus galloprovincialis) in Spain with special reference to the copepod, Mytilicola intestinalis. Aquaculture 127:287-302

Rybakov AV, Kholodkovskaya EV (1987) Parasites and commensals of the mussel Mytilus galloprovincialis in the Northwest Black Sea. Biol Morya 2:22-29

Sagristà E, Bozzo MG, Bigas M, Poquet M, Durfort M (1998) Developmental cycle and ultrastructure of Steinhausia mytilovum, a microsporidian parasite of oocytes of the mussel, Mytilus galloprovincialis (Mollusca, Bivalvia). Eur J Protistol 34:58-68

Shaw BL, Battle HI (1957) The gross and microscopic anatomy of the digestive tract of the oyster Crassostrea virginica (Gmelin). Can J Zool 35:325-347

Sprague V (1965) Observations on Chytridiopsis mytilovum (Field), formerly Haplosporidium mytilovum Field, (Microsporida?). J Protozool 12:385-389

Villalba A, Carballal MJ, López MC (1993) Pathologic conditions of three carpet shell clam species of Galicia (NW. of Spain). Proc of World Aquaculture '93 - from discovery to commercialization. Torremolinos, Spain. European Aquaculture Society, Oostende, p 85

Villalba A, Mourelle SG, Carballal MJ, López C (1997) Symbionts and diseases of farmed mussels Mytilus galloprovincialis throughout the culture process in the Rías of Galicia (NW Spain). Dis Aquat Org 31:127-139

Wittner M, Weiss LM (1999) The Microsporidia and microsporidiosis. American Society of Microbiology, Washington, DC

Submitted: May 6, 2003; Accepted: November 25, 2003

Proofs received from author(s): February 19, 2004
Editorial responsibility: Albert Sparks, Seattle, Washington, USA

Proofs received from author(s): February 19, 2004 